\title{
THE EFFECT OF DIETARY VITAMIN E AND ZINC LEVELS ON PERFORMANCE AND LIPID OXIDATION IN FRESH AND STORED EGGS OF LAYING DUCKS
}

\section{PENGARUH LEVEL VITAMIN E DAN ZINK DALAM RANSUM TERHADAP PERFORMA DAN OKSIDASI LEMAK PADA TELUR ITIK SEGAR DAN SETELAH DISIMPAN}

\author{
Arif Darmawan*, Sumiati, and Widya Hermana \\ Department of Nutrition and Feed Technology, Faculty of Animal Science, Bogor Agricultural University, \\ Bogor, 16680
}

Submitted: 31 October 2016, Accepted: 3 March 2017

\section{INTISARI}

Vitamin E dan zink berperan penting untuk mencegah kerusakan akibat radikal bebas pada membran phospolipid, enzim dan beberapa molekul lainnya. Tujuan penelitian ini adalah untuk mengevaluasi efek penambahan vitamin $E$ dan zink terhadap performa dan oksidasi lemak pada kuning telur segar dan disimpan selama 21 hari. Penelitian ini menggunakan 90 ekor itik petelur umur 22 minggu yang dipelihara selama 8 minggu. Rancangan yang digunakan adalah Rancangan Acak Lengkap yang terdiri dari 5 perlakuan dan 3 ulangan. Perlakuan yang diberikan adalah R1 (ransum kontrol), R2 (R1+40 IU vitamin E), R3 (R1+80 IU vitamin E), R4 (R1+100 ppm zink organik), dan R5 (R1+200 ppm zink organik). Parameter yang diamati adalah konsumsi, produksi telur, berat telur, konversi pakan dan nilai Thiobarbituric Acid Reactive Substances (TBARS) kuning telur. Hasil penelitian ini menunjukkan bahwa penggunaan vitamin E sampai 80 IU dan zink sampai 200ppm tidak mempengaruhi konsumsi dan berat telur. Penggunaan vitamin $E$ dan zink organik dapat menurunkan konversi pakan dan meningkatkan produksi telur secara signifikan $(P<0.05)$ serta efektif menurunkan nilai TBARS. Kesimpulan penelitian ini adalah penggunaan $40 \mathrm{IU}$ vitamin E atau 100 ppm zink organik mampu meningkatkan performa dan penggunaan 200 ppm zink organik lebih efektif sebagai antioksidan.

(Kata kunci: Antioxidan, Performa, Vitamin E, Zink organik)

\section{ABSTRACT}

Vitamin $E$ and zinc are necessary for preventing free radical damage to phospholipid membranes, enzymes and other important molecules. The objective of this study was to evaluate the effect of dietary vitamin $E$ and zinc levels on performance and lipid oxidation in fresh and stored eggs of laying duck. A total of 90 of 22 weeks old ducks were randomly divided into 15 experimental units by assigning a completely randomized design with 5 treatments and 3 replications. The treatment diets were R1 (control diet), R2 (R1+40 IU vitamin E), R3 (R1+80 IU vitamin E), R4 (R1+100 ppm organic zinc), and R5 (R1+200 ppm organic zinc).The experiment was carried out for 8 wk. Parameters observed were feed intake, egg production, egg weight, feed conversion ratio, and Thiobarbituric Acid Reactive Substances (TBARS) value. The results showed that increasing of vitamin E from $40 \mathrm{IU}$ to $80 \mathrm{IU}$ and zinc from $100 \mathrm{ppm}$ to $200 \mathrm{ppm}$ did not affect feed intake and egg weight. Otherwise, the dietary Vitamin $\mathrm{E}$ and organic zinc significantly decreased $(P<0.05)$ feed conversion ratio and significantly increased $(P<0.05)$ egg production and decreased $(P<0.01)$ TBARS values. It is concluded that dietary $40 \mathrm{IU}$ vitamin $E$ or $100 \mathrm{ppm}$ organic zinc could increase the performance of laying ducks and dietary $200 \mathrm{ppm}$ organic zinc was more efective to be antioxidant than 40 and $80 \mathrm{IU}$ vitamin $\mathrm{E}$.

(Key words: Antioxidant, Organic zinc, Performance, Vitamin E)

\footnotetext{
* Korespondensi (corresponding author):

Telp. +6285658804040

E-mail: arif_darma79@yahoo.com
} 


\section{Introduction}

Egg is recognized as source of omega3 and omega- 6 fatty acids. Omega-3 and omega- 6 in egg have an important role for brain function and integrity, as well as in the formation and growth of the brain and preventing cardiovascular disease (Hardini et al., 2006; Simopoulos, 2002). Unfortunately, omega-3 and omega-6 fatty acid are easily oxidized during storage (Rahimi et al., 2011). Therefore, it need to be protected by the inclusion of antioxidants in the diets. Antioxidants has a role for breaking the chain of peroxide in membranes and protecting polyunsaturated fatty acids from oxidation (Young and Woodside, 2001).

Vitamin $\mathrm{E}$ and zinc can be added to ducks diet as natural antioxidants that can be metabolized and transferred into the egg. Vitamin $E$ content in yolk egg increases by increasing level of dietary addition (Radwan et al., 2008). Dietary vitamin $E$ has been demonstrated to beneficially affect enhancement of lipid stability in eggs (Cherian et al., 1996). Vitamin $\mathrm{E}$ is fat soluble and as antioxidants has a role for breaking the chain of peroxide in membranes and protecting polyunsaturated fatty acids from oxidation (Kirunda et al., 2001). According to Biswas et al. (2010) vitamin E plays an important role in avian reproduction and it can increase egg production. Canan et al. (2007), reported that egg production of laying hen increased significantly under heat stressed group and a non-heat stressed group with the supplementation of dietary vitamin $\mathrm{E}$. In addition, zinc has important roles in the organism because it is a cofactor of more than 200 enzymes (Bahakaim et al., 2014) and one of the most significant functions of zinc is its participation in the antioxidant defense system (Powell, 2000; Rink and Kirchner, 2000). According to Bahakaim et al. (2014), increasing zinc levels from 0.0 up to 150 ppm either as inorganic or organic significantly increased egg zinc concentration.

The inclusion of antioxidants into poultry diets can improve oxidative stability of eggs as reflected by decreased egg yolk Thiobarbituric Acid Reactive Substances (TBARS) levels (mg MDA/kg). According to Akdemir and Sahin (2009), dietary antioxidant and MDA concentration in poultry products have inverse relationship. MDA is one of the final products of polyunsaturated fatty acids peroxidation and it is commonly known as a marker of oxidative stress (Dauqan et al., 2013). Sahin et al. (2006) reported that quail supplemented with dietary vitamin $E$ as antioxidant had a significant reduction in malondialdehyde (MDA) values in serum. Therefore the study evaluated the effect of dietary vitamin $\mathrm{E}$ and Zinc on performance and lipid oxidation of laying duck egg.

\section{Materials and Methods}

\section{Birds and management}

Ninety of 20 weeks old Magelang ducks with an average body weight of $1.67 \pm 0.07 \mathrm{~kg}$ used in this study were randomly divided into five treatments and housed on rice husks in floor pen of same size $(2.0 \mathrm{~m} \times 2.0 \mathrm{~m})$. Each pen was equipped with one feeder and two water bowels with 3 I water capacity. Incandescent light bulbs were used as lighting and applied for 16 hours. During the experimental period, pellet diet and water were provided ad libitum. The average relative humidity and temperature in the house were recorded three times a day (morning, afternoon and night).

\section{Dietary treatments}

This study used a completely randomized design with 5 treatments and 3 replications. The diet was formulated base on Leeson and Summers (2005) standard (2850 kcal ME / kg metabolizable energy and 16\% protein). The composition and nutrients content in the experimental diets is presented in Table 1. The treatment diets were R1 (control diet), R2 (R1+40 IU vitamin E), R3 (R1+80 IU vitamin E), R4 (R1+100 ppm organic zinc), and R5 (R1+200 ppm organic zinc). The ducks were given adaptation periode for 2 weeks at the age of 20-22 weeks to introduce the treatment diet. The pattern of diet adaptation was $75 \%$ of commercial ration (CR) and 25\% treatment diet (TD) during 4 days, 50\% CR and 50\% TD during 4 days, 25\% CR and 75\% TD during 3 days and 0\% CR and 100\% TD for the last 3 days. Treatment diets were fed for $8 \mathrm{wk}$ at 22-30 weeks of age.

\section{Traits measured}

Eggs weight (g/egg) were weighed daily and and then at the end of each experimental week average egg weight was calculated, feed intake and feed conversion ratio were recorded weekly. Egg production (\%) was calculated by dividing egg number 
Table 1. The composition and nutrients content of control diet (as fed) (Sumiati et al., 2015)

\begin{tabular}{|c|c|}
\hline Feed Ingredient & $(\%)$ \\
\hline Yellow corn & 46 \\
\hline Rice bran & 15.2 \\
\hline Soybean meal & 19 \\
\hline Fish meal & 8 \\
\hline Palm oil & 3.5 \\
\hline Fish oil & 1 \\
\hline $\mathrm{CaCO} 3$ & 6.5 \\
\hline $\mathrm{NaCl}$ & 0.2 \\
\hline Premix & 0.5 \\
\hline DL-Methionin & 0.1 \\
\hline Total & 100 \\
\hline \multicolumn{2}{|l|}{ Nutrient content } \\
\hline Crude protein*(\%) & 16.0 \\
\hline Crude fiber*(\%) & 10.3 \\
\hline Crude fat* $(\%)$ & 3.52 \\
\hline Calsium*(\%) & 3.02 \\
\hline Avialable phosphorus * $(\%)$ & 0.43 \\
\hline Methionine ${ }^{\star \star}(\%)$ & 0.46 \\
\hline Methionine + Cystine ${ }^{\star \star}(\%)$ & 0.71 \\
\hline$A c h *(\%)$ & 125 \\
\hline Metabolizable energy** (kcal /kg) & 2855 \\
\hline $\begin{array}{l}\text { *Analysis at Laboratory of Nutrition and Feed Tech } \\
2014,{ }^{* *} \text { calculated value } \\
\text { Premix provided (in mg/kg premix): vit A } 500.000 \mathrm{Il} \\
250 \mathrm{mg} \text {; vit B12 } 250 \mathrm{mcg} \text {; niacinamide } 375 \mathrm{mg} \text {; Ca- } \\
\text { Glysine } 3.750 \mathrm{mg} \text {; Dl-methionine } 5.000 \mathrm{mg} \text {; } \mathrm{Mg} \text { sulf } \\
\text { mg; Zn sulfat } 500 \mathrm{mg} \text {; K iodine } 5 \mathrm{mg}\end{array}$ & $\begin{array}{l}\text { University, } \\
\text { o mg; vit B2 } \\
\text { ide } 5.000 \mathrm{mg} \text {; } \\
\text { Cu sulfat } 25\end{array}$ \\
\hline
\end{tabular}

with the birds on each day. Lipid peroxidation of egg was determined using Thiobarbituric Acid Reactive Substances (TBARS) by RiceEvans and Anthony (1991) method. Then, the activity of TBARS values was identified using spectrophotometer. Two eggs from each replications were separated to be analyzed TBARS value as fresh yolk egg and to be stored 21 days at room temperature. After 21 days, yolk eggs were measured for TBARS value.

\section{Statistical analysis}

The experiment was designed and statistically analyzed as a completely randomized design. Each of the five treatment was assigned to three replicated pens with six birds each. Analysis of variance of data was performed using SPSS vr.21.0 program.
Differences were considered significant at a probability level of $P<0.05$. If significant of main effect was detected, then means were compared using Duncan's multiple range test.

\section{Results and Discussion}

\section{Feed intake}

The average feed intake ranged from 166.02 to $170.56 \mathrm{~g} /$ duck/ day (Table 2) and treatments had no significant effect on feed intake. This was probably due to the similarity of shape feed and energy content in diet which resulted equall palatability. Ferket and Gernat (2006) stated that feed intake was influenced by the shape of rations, color and palatability. Feed intake of this study was smaller than managed by the farmers in general (160 to 200 g/duck/day) (Sasongko, 
2010). Chen and Shen (1989) reported that Tsaiya laying duck (Taiwan local ducks with the body size was almost the similar to Bantul duck) showed the results of feed intake ranged from 205 to $225 \mathrm{~g} /$ duck /day with feed on mash form. The lower feed intake in this study was probably due to the high ambient temperature. The temperature in this study was $33.3-36.7{ }^{\circ} \mathrm{C}$ by day and it was higher than the recommended thermoneutral zone of $18-24^{\circ} \mathrm{C}$ for poultry in the tropical regions (Holik, 2009). Wilson et al. (1980) stated that ideal temperature for ducks and laying hens between 18.3 to $25.5^{\circ} \mathrm{C}$ and feed intake, production and quality of eggs greatly reduced at $30-32^{\circ} \mathrm{C}$.

\section{Egg weight}

The average of egg weight in this study ranged from 69.54-71.61 g/ egg (Table 2) . It was greater than the finding of Darmawan et al. (2013) who reported that egg weight of ducks was $56.60 \mathrm{~g}$ with 22,89 g/duck/day protein consumption. The difference was possibly due to the high protein consumption. The average of protein consumption in this study was $26.92 \mathrm{~g} / \mathrm{bird} / \mathrm{day}$. Ketaren and Prasetyo (2002) reported that protein consumption on 20-43 wk of age was 26.65 $\mathrm{g} / \mathrm{bird} / \mathrm{d}$. According to Leeson and Summers (2005), protein and/or amino acids (especially methionine) are the most nutrients that have important role in controlling the size of eggs. Fish oil in the diet did not affect egg size but affect the composition of the fat content in the yolk (Suripta and Astuti, 2006). In another study, Bozkurt et al. (2009) showed that essential oil supplementation in diet did not affect egg weight of broiler breeders.

\section{Feed conversion}

The treatments had significant effect on feed conversion, ranging between 6.66-8.20
(Table 2). Addition of Vitamin E and organic zinc decreased significantly feed conversion ratio that was due to by the increasing of egg production, while feed intakes were not significantly different. According to Leeson and Summers (2005), factors that affect feed conversion are eggs production, energy and nutrient content of the feed, body weight, and temperature. The feed conversion in this study was bigger than reported by Zubaidah (2001) that feed conversion for laying duck on 28 week of age was $5.55-6.70$ and it was also bigger than reported by Darmawan et al. (2013) that using balance of omega-3 and omega- $6=1$ : 4.5 and 200 ppm organic zinc in mash form diet. The higher FCR was probably caused by the reduction of feed intake and egg production. The reduction of feed intake might be due to the diet form which was able to influence feed palatability and consumption (Vilarino et al., 1996) and according to ElDeek and Brikaa (2009) ducks consumed higher mash diet than pellet diet.

\section{Egg production}

Addition of vitamin $\mathrm{E}$ and organic zinc increased significantly egg production than control. According to Ashok and Sushil (2005), the relationship of vitamin $E$ with reproduction is the role of vitamin $E$ as an antioxidant that can prevent the fat oxidation. Vitamin $E$ is fat soluble and as antioxidants has a role for breaking the chain of peroxide in membranes and protecting polyunsaturated fatty acids from oxidation (Raederstorff et al., 2015). Use of 100 ppm to 200 ppm organic zinc was also able to increase the eggs production. The presence of zinc is very beneficial to the metabolic transformation of omega-3 and omega-6 fatty acid to prostaglandins that play a role in the reproductive system (Bhowmik et al., 2010).

Table 2. Average of feed intake, egg weight and feed conversion ratio of laying ducks

\begin{tabular}{llcccc}
\hline \hline \multirow{2}{*}{ Parameters } & \multicolumn{5}{c}{ Treatments } \\
\cline { 2 - 6 } & \multicolumn{1}{c}{$\mathrm{R} 1$} & $\mathrm{R} 2$ & $\mathrm{R} 3$ & $\mathrm{R} 4$ & $\mathrm{R} 5$ \\
\hline $\begin{array}{l}\text { Feed intake } \\
\text { (g/duck/day) }\end{array}$ & $167,18 \pm 1,59$ & $167,96 \pm 3,08$ & $170,56 \pm 1,64$ & $168,87 \pm 2,58$ & $166,92 \pm 3,94$ \\
Egg weight (g/egg) & $71,17 \pm 2,42$ & $69,54 \pm 1,77$ & $68,77 \pm 2,55$ & $69,71 \pm 4,21$ & $71,61 \pm 2,60$ \\
$\begin{array}{l}\text { Feed conversion } \\
\text { ratio }\end{array}$ & $8.20 \pm 0.34^{\mathrm{b}}$ & $6.66 \pm 0.72^{\mathrm{a}}$ & $6,96 \pm 0.64^{\mathrm{a}}$ & $6.85 \pm 0.43^{\mathrm{a}}$ & $6.99 \pm 0.66^{\mathrm{a}}$ \\
Egg production (\%) & $28.77 \pm 0.45^{\mathrm{a}}$ & $36.90 \pm 3.8^{\mathrm{b}}$ & $35.02 \pm 1.8^{\mathrm{b}}$ & $36.51 \pm 0.34^{\mathrm{b}}$ & $35.52 \pm 5.80^{\mathrm{b}}$ \\
\hline $\begin{array}{l}\text { a,b Mean in the same raw with different superscripts differ significantly (P 0.05). } \\
\text { R1 (diet without Vitamin E and organic zinc), R2 (R1+40 IU vitamin E), R3 (R1+80 IU vitamin E), R4 (R1+100 ppm }\end{array}$
\end{tabular}


Table 3. Thiobarbituric acid reactive substances (TBARS) values (mg MDA/100 g ) of egg yolk

\begin{tabular}{ccc}
\hline \hline Treatments & \multicolumn{1}{c}{ Fresh } & Stored during 21 days \\
\hline R1 & $1.64 \pm 0.41^{\mathrm{ab}^{\star}}$ & $3.15 \pm 0.27^{\mathrm{A}^{\star \star}}$ \\
$\mathrm{R} 2$ & $1.01 \pm 0.10^{\mathrm{bc}}$ & $2.63 \pm 0.07^{\mathrm{A}}$ \\
$\mathrm{R} 3$ & $1.52 \pm 0.28^{\mathrm{ab}}$ & $2.44 \pm 0.63^{\mathrm{A}}$ \\
$\mathrm{R} 4$ & $1.90 \pm 0.75^{\mathrm{a}}$ & $2.49 \pm 0.22^{\mathrm{A}}$ \\
R5 & $0.74 \pm 0.10^{\mathrm{c}}$ & $1.09 \pm 0.20^{\mathrm{B}}$ \\
\hline${ }^{*}$ Mean in the same coloumn with different superscripts differ significantly $(\mathrm{P}<0.05)$. \\
${ }^{*}$ Means in the same row with different superscripts differ very significantly $(\mathrm{P}<0.01)$. \\
R1 (diet without vitamin E and organic zinc), R2 (R1+40 IU vitamin E), R3 (R1+80 IU vitamin E), R4 (R1+100 ppm \\
organic zinc), and R5 (R1+200 ppm organic zinc).
\end{tabular}

Bachri et al. (2006) reported that the used of $112.5 \mathrm{mg}$ zinc increased egg production significantly because the zinc mineral can activate amino peptidase and carboxcypeptidase enzymes and provide sufficient amino acids for the formation of the egg. Darmawan et al. (2013) reported that dieats containing the ratio of omega-3 : omega- $6=1: 3$ and 200 ppm organic zinc produced highest egg production significantly.

\section{Thiobarbituric acid reactive substances (TBARS)}

TBARS is the most generally used to determine lipid oxidation in a product (Cherian et al., 2002). TBARS value of R5 (diet without vitamin $E$ and organic zinc +200 ppm organic zinc) in fresh egg yolk was lower $(P<0.05)$ compared to R1 (diet without vitamin $\mathrm{E}$ and organic zinc +200 ppm organic zinc), R3 (diet without vitamin $E$ and organic zinc +80 IU vitamin E) and R4 (diet without vitamin E and organic zinc+100 ppm organic zinc) (Table 3). The addition of zinc in duck diet was effective to be antioxidant that prevent the damage of omega-3 and omega-6 from oxidation process. According to Camps et al. (1992), zinc protects fatty acids from peroxidation by inhibiting the production of reactive oxygen species. TBARS value of egg yolk stored at room temperature $\left(29.29-30.07^{\circ} \mathrm{C}\right)$ during 21 days was higher than fresh eggs. These results are in agreement with previous reports that showed that TBARS values were increased in eggs during storage time (Shahryar et al., 2010). The increased TBARS values in egg yolk during storage time was caused by the oxidative deterioration of long-chain unsaturated fatty acids in egg yolks (Laika and Jahanian, 2015). TBARS value of R5 was lower $(P<0.01)$ than R1, R2, R3, and
R4 after being stored during 21 days at room temperature (Table 3 ). This showed that the use of 200 ppm organic zinc in the ration was able to suppress the damage of fatty acids due to the oxidation process in fresh eggs or stored during 21 days at room temperature. The reduced lipid peroxidation by addition of zinc in diet might be due to the increasing of metallothionein syntesis. Zinc increases metallothionein syntesis which has a function as free radical scavenger (Salgueiro et al., 2000). According to Orlova and Orlov (2011), zinc is a cofactor of the main antioxidative enzyme CuZn-superoxide dismutase which can reduce oxidative damage caused by free radicals. A further explanation could be that zinc may increase the stability of egg yolk lipids through superoxide dismutase that have optimal activity to prevent the initiation of lipid peroxidation.

\section{Conclusion}

Dietary of $40 \mathrm{IU}$ vitamin E or 100 ppm organic zinc could decrease feed conversion ratio and increase egg production of laying ducks and dietary 200 ppm organic zinc was more efective to be antioxidant.

\section{Acknowledgement}

This research was funded by Indonesian Ministry of Education and Culture, Directorate General of Higher Education with contract number: 77 /IT3.11/LT/2014.

\section{References}

Akdemir, F. and K. Sahin. 2009. Genistein supplementation to the quail: effects on egg production and egg yolk genistein, 
daidzein, and lipid peroxidation levels. Poult. Sci. 88: 2125-2131.

Ashok, A. and A. Sushil. 2005. Oxidative stress and antioxidants in male infertility: difficult balance. Iranian $\mathrm{J}$. Reprod. Med. 3: 1-8.

Bachri, I., Roeswandy and A. Nasution. 2006. Pemanfaatan solid dekanter dan suplementasi mineral Zinkum dalam ransum terhadap produksi burung puyuh (Cortunix- cortunix japonica) umur 6-17 minggu dan daya tetas. J. Agrib. Pet. 2: 72-77.

Bahakaim, A. S. A., H. A. A. Magied, S. M. H. Osman, A. S. Omar, N. Y. A. Malak and N. A. Ramadan. 2014. Effect of using different levels and sources of zinc in layer's diets on egg zinc enrichment. Egypt. Poult. Sci. 34: 39-56

Bales, C. W., R. A. DiSilvestro, K. L.Currie, C. S. Plaisted, H. Joung, A. N. Galanos and P. H. Lin. 1994. Marginal zinc deficiency in older adults: responsiveness of zinc status indicators. J. Am. Coll. Nutr. 13: 455462.

Bhowmik, D., Chiranjib and K. P. Kumar. 2010. A Potential medicala importance of zinc in human health and chronic disease. Int. J. Pharm. Biomed. Sci. 1: 5-11.

Biswas, A., J. Mohan and K. V. H. Sastry. 2010. Effect of vitamin e on production performance and egg quality traits in indian native Kadaknath He. AsianAust. J. Anim. Sci. 23: 396-400.

Bozkurt, M., A. Alçiçek, M. Çabuk, K. Kuçukyilmaz and A. U. Çatli. 2009. Effect of an herbal essential oil mixture on growth, laying traits, and egg hatching characteristics of broiler breeders. Poult. Sci. 88: 2368-2374.

Camps, J.,T. Bargallo, A. Gimenez, S. Alie and J. Caballeria, A. Pares, J. Jovan, L. Masana, J. Rodes. 1992. Relationship between hepatic lipid peroxidation and fibrogenesis in carbon tetrachloridetreated rats: effect of zinc administration. Clin. Sci. 83: 695-700.

Canan, S. B., M. K. Erhan, M. S. Keles and R. Kocyigit. 2007. Effect of dietary vitamin e on performance, plasma and egg yolk vitamin e levels and lipid oxidation of egg in heat stressed layers. J. Appl. Biol. Sci. 1: 19-23.

Chen, W. L. and T. F. Shen. 1989. Comparative studies on the ulitilization of calcium between laying Tsaiya Duck and Leghorn Hen. Asian-Aust. J. Anim. Sci. 2: 67-75.

Cherian, G., F. W. Wolfe and J. S. Sim. 1996. Feeding dietary oils with alpha tocopherols: Effects on internal qualities of eggs during storage. $\mathrm{J}$. Food Sci. 61: 15-18.

Cherian, G., R. K. Selvaraj, M. P. Goeger and P. A. Stitt. 2002. Muscle fatty acid composition and thiobarbituric acidreactive substances of broilers fed different cultivars of sorghum. Poult. Sci. 81: 1415-1420.

Darmawan, A., K. G. Wiryawan and Sumiati. 2013. Egg production and quality of Magelang duck fed diets containing different ratio of omega 3 : omega 6 and organic zn. Med. Pet. 36: 197-202. DOI: 10.5398/medpet.2013.36.3.197.

Dauqan, E., A. Abdullah and H. A. Sani. 2013. Lipid peroxidation in rat liver using different vegetable oils. The Malay. J. Analytical. Sci.17: 300-309.

El-Deek, A. A. and A. M. Brikaa. 2009. Effect of different levels of seaweed in starter and finisher diets in pellet and mash form on performance and carcass quality of ducks. Int. J. Poult. Sci. 8: 1014-1021.

Ferket, P. R and A. G. Gernat. 2006. Factors that affect feed intake of meat birds. Int. J. Poult. Sci. 5: 905-911.

Hardini, D., T. Yuwanta, Zuprizal and Supadmo. 2006. The change in cholesterol content of long chain fatty acid egg during processing and its influence to the Rattus norvegicus $L$. blood cholesterol content. Jurnal IImu Ternak Veteriner 11: 260-265.

Holik, V. 2009. Management of laying hens to minimize heat stress. Lohmann Information. 44:16-29.

Ketaren, P. P. dan L. H. Prasetyo. 2002. Pengaruh pemberian pakan terbatas terhadap produksi telur itik silang Mojosari x Alabio (MA): 1. Masa bertelur fase pertama umur 20-43 minggu. Jurnal IImu Ternak Veteriner 7: 38-45.

Kirunda, D. F. K., S. E. Scheideler and S. R. McKee. 2001. The efficacy of vitamin $E$ (dl-alpha-tocopheryl acetate) supplementation in hen diets to alleviate egg quality deterioration associated with high temperature exposure. Poult. Sci. 80: 1378-1383. 
Laika, M. and R. Jahanian. 2015. Dietary supplementation of organic selenium could improve performance, antibody response, and yolk oxidative stability in laying hens fed on diets containing oxidized fat. R. Biol.Trace. Elem. 165: 195.

Leeson, S. and J. D. Summers. 2005. Commercial Poultry Nutrition. 3 rd Ed. Department of Animal and Poultry Science, University of Guelph. University Books, Guleph.

Orlova, M. A. and A. P. Orlov. 2011. Role of zinc in an organism and its influence on processes leading to apoptosis. British. J. Medic. Research. 1: 239-305.

Powell, S. R. 2000. The antioxidant properties of zinc. J. Nutr. 1452-1456.

Radwan, N. L., R. A. Hassan, E. M. Qota and H. M. Fayek. 2008. Effect of natural antioxidant on oxidative stability of eggs and productive and reproductive performance of laying hens. Int. J. Poult. Sci. 7: 134-150.

Raederstorff, D., A. Wyss, P. C. Calder, P. Weber and M. Eggersdorfer. 2015. Vitamin $E$ function and requirements in relation to PUFA. Br. J. Nutr. 114: 11131122.

Rahimi, S., S. K. Azad and M. A. K.Torshizi. 2011. Omega-3 enrichment of broiler meat by using two oil seeds. J. Agr. Sci. Tech. 13: 353-365.

Rice-Evans, C. and T. D. Anthony. 1991. Techniques in free radical research. Elsevier, pp: 146-202.

Rink, L. and H. Kirchner. 2000. Zinc-altered immune function and cytokine production. J. Nutr. 130: 1407-1411.

Sahin, N., K. Sahin, M. Onderci, M. Karatepe, M. O. Smith and O. Kucuk. 2006. Effects of dietary lycopene and vitamin $E$ on egg production, antioxidant status and cholesterol levels in japanese quail. Asian-Aust. J. Anim. Sci. 19: 224230.

Salgueiro, M. J., M. Zubillaga, A. Lysionek, M. I. Sarabia, R. Caro, T. De Paoli, A. Hager, R. Weill and J. Boccio. 2000. Zinc as essential micronutrient: a review. Nutr. Res. 20: 737-755.

Sasongko, H. 2010. Feeding management evaluation of duck farmer group in Brebes. Proceedings of the 5th
International Seminar on Tropical Animal Production, Universitas Gadjah Mada. 364-367.

Shahryar, H. A., R. Salamatdoust, S. Chekani-Azar, F. Ahadi and T. Vahdatpoor. 2010. Lipid oxidation in fresh and stored eggs enriched with dietary $\omega 3$ and $\omega 6$ polyunsaturated fatty acids and vitamin $E$ and $A$ dosages. Afric. J. Biotech. 9: 18271832.

Simopoulos, A. P. 2002. Omega-3 fatty acids in inflammation and autoimmune diseases. J. Amer. Coll. Nutr. 21: 495505.

Sumiati, W. Hermana, A. Darmawan, and N. Nuraeni. 2015. The effect of feeding Zinc ( $\mathrm{Zn})$ and vitamin $\mathrm{E}$ fortified diets on duck egg quality stored at different temperature during 21 days. Proceeding $4^{\text {th }}$ ISAINI "Recent Advance in Animal and Feed Technology to Support Sustainable Livestock Production System". Manado. Pp. 3039.

Suripta, H. dan P. Astuti. 2006. Pengaruh penggunaan minyak lemuru dan minyak sawit dalam ransum terhadap rasio asam lemak omega-3 dan omega-6 dalam telur burung puyuh (Coturnix coturnix japonica). J. Indon. Trop. Anim. Agric. 32: 22-27.

Vilarino, M., M. L. Picard, J. P. Melcion and J. M. Faure. 1996. Behavioural adaptation of laying hens to dilution of diets under mash and pellet form. Br. Poult. Sci. 37: 895-907.

Wilson, E. K., F. W. Pierson, P. Y. Hester, R. L. Adams and W. J. Stadelman. 1980. The of high environmental temperature on feed passage time and performance of Pekin ducks. J. Poult. Sci. 23222325.

Young, I. S. and J. V. Woodside. 2001. Antioxidants in health and disease. $\mathrm{J}$. Clin. Pathol. 54: 176-186.

Zubaidah. 2001. Kualitas telur itik hasil persilangan Alabio dengan bibit induk CV 2000 pada generasi pertama dengan kandang litter. J. Peternakan Lingkungan 7: 13-18. 